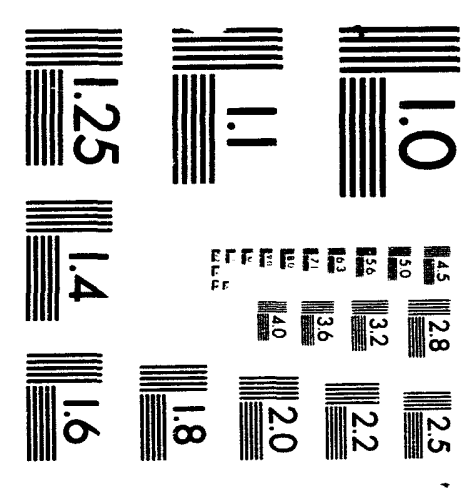



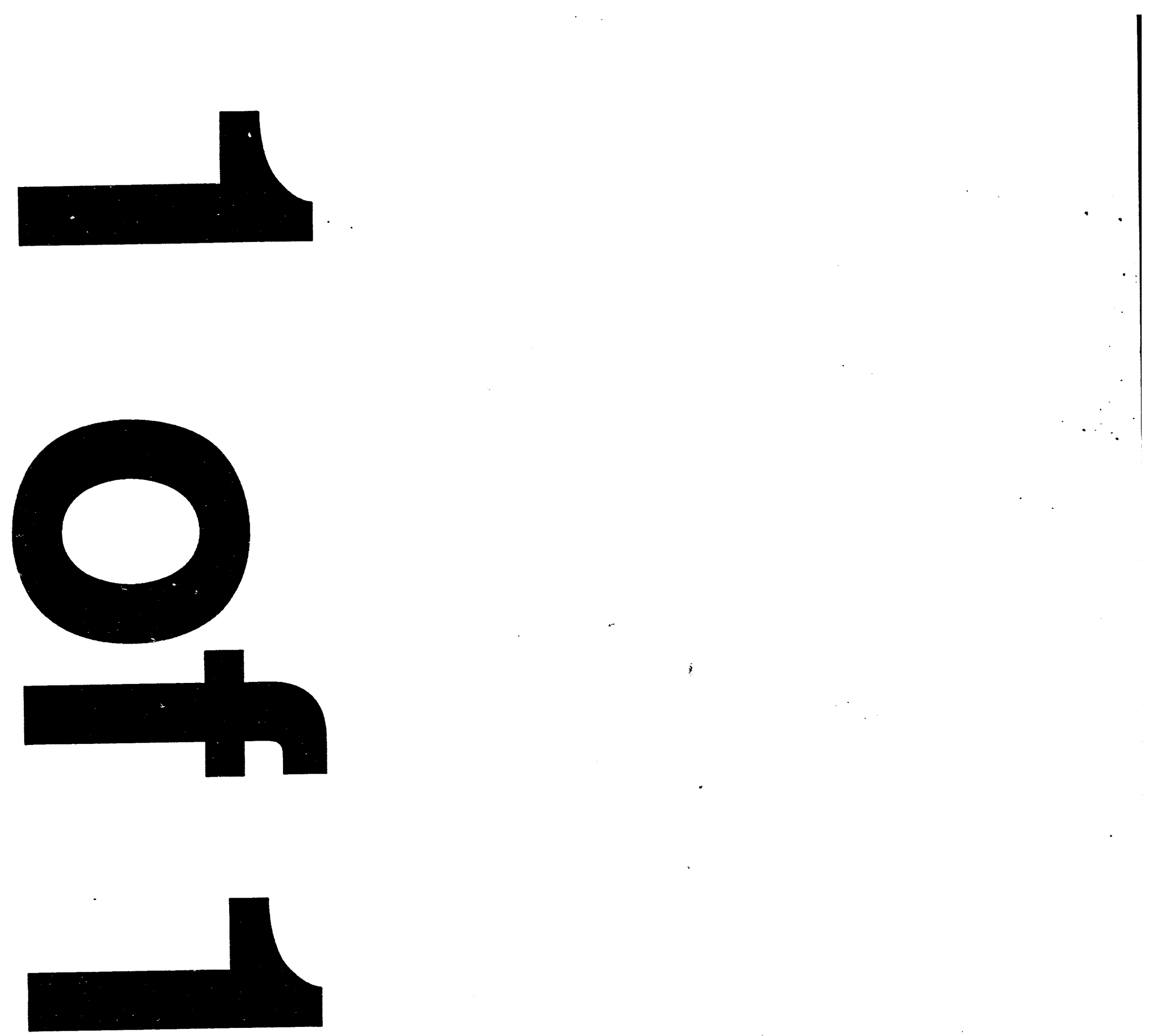

- 


\title{
TANK 29 SALT REMOVAL METHOD USING SLURRY PUMP AGITATION
}

by

W. R. Parish

Westinghouse Savannah River Company

Savannah River Site

Aiken, South Carolina 29808

\section{DISCLAIMER}

\begin{abstract}
This report was prepared as an account of work sponsored by an agency of the United States Government. Neither the United States Government nor any agency thereof, nor any of their employees, makes any warranty, express or implied, or assumes any legal liability or responsibility for the accuracy, completeness, or usefulness of any information, apparatus, product, or process disclosed, or represents that its use would not infringe privately owned rights. Reference herein to any specific commercial product, process, or service by trade name, trademark, manufacturer, or otherwise does not necessarily constitute or imply its endorsement, recommendation, or favoring by the United States Government or any agency thereof. The views and opinions of authors expressed herein do not necessarily state or reflect those of the United States Government or any agency thereof.
\end{abstract}

\section{DOE Contract No. DE-AC09-89SR18035}

This paper was prepared in connection with work done under the above contract number with the U. S.

Department of Energy. By acceptance of this paper, the publisher and/or recipient acknowledges the U. S. Government's right to retain a nonexclusive, royalty-free license in and to any copyright covering this paper, along with the right to reproduce and to authorize others to reproduce all or part of the copyrighted paper.

$$
\text { M. TER }
$$




\section{DISCLAIMER}

This report was prepared as an account of work sponsored by an agency of the United States Government. Neither the United States Government nor any agency thereof, nor any of their employees, makes any warranty, express or implied, or assumes any legal liability or responsibility for the accuracy, completeness, or usefulness of any information, apparatus, product, or process disclosed, or represents that its use would not infringe privately owned rights. Reference herein to any specific commercial product, process, or service by trade name, trademark, manufacturer, or otherwise does not necessarily constitute or imply its endorsement, recommendation, or favoring by the United States Government or any agency thereof. The views and opinions of authors expressed herein do not necessarily state or reflect those of the United States Government or any agency thereof.

This report has been reproduced directly from the best available copy.

Available to DOE and DOE contractors from the Office of Scientific and Technical Information, P. O. Box 62, Oak Ridge, TN 37831; prices available from (615) $576-8401$.

Available to the public from the National Technical Information Service, U. S. Department of Commerce, 5285 Port Royal Rd., Springfield, VA 22161 
HIGH LEVEL WASTE ENGINEERING

WASTE REMOVAL PROGRAMS SECTION

TANK 29 SALT REMOVAL METHOD USING

SLUṚRY PUMP AGITATION(U)

BY

W. R. PARISH

ISSUED: November 30, 1993
WSRC-TR-93-609

REVISION: 0

KEYWORDS:

Tank 29

Salt Removal

Waste Removal

Plan

RETENTION:

PERMANENT

CLASSIFICATION:

Tanl D.d'Euthenn
Authorized Derivative Classifier
18 Nov 93

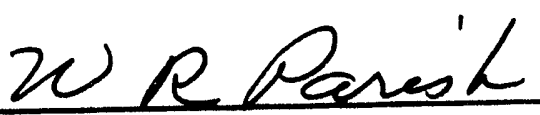

Author/Authenticator

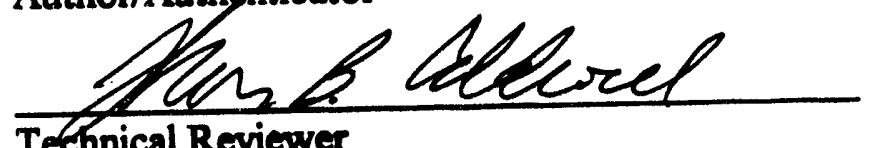

Teehnical Reviewer

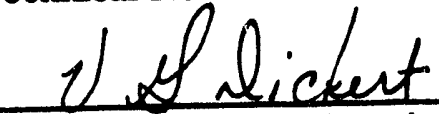

Manager, HLW Engineering

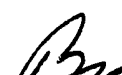

Manager, Waste Removal Engineering

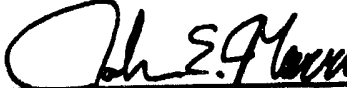

Manhger, HLWE Technical Support
Date: $11 / 18 / 93$

Date: $11 / 18 / 93$

Date: $\quad 11 / 22 / 93$

Date: $11 / 22 / 73$

Date: $11 / 18 / 93$ 


\section{CONTENTS}

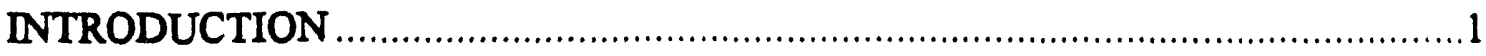

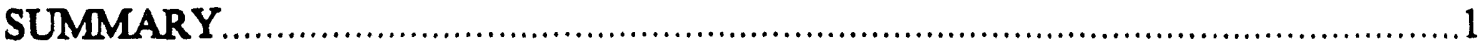

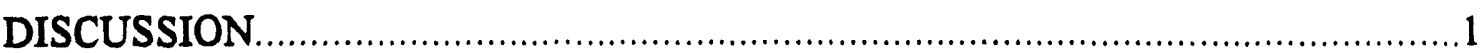

History of Tank 29 ............................................................................

Comparison with Past Salt Removal Projects ...........................................

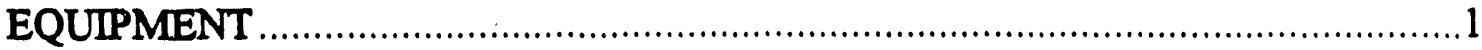

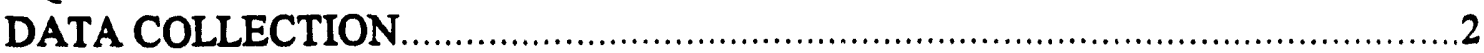

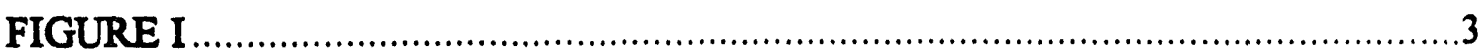

METHOD OF SALT REMOVAL FROM TANK 29 .......................................

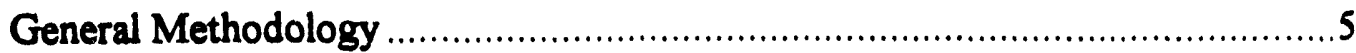

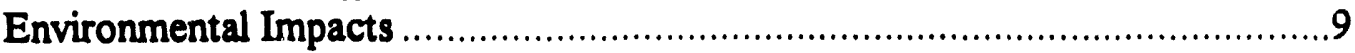

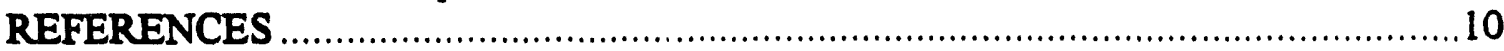

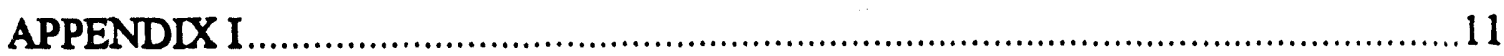

Differences Between Tank 16 \& Tank 19 Experience And

The Present Situation In Tank 29........................................................... 12

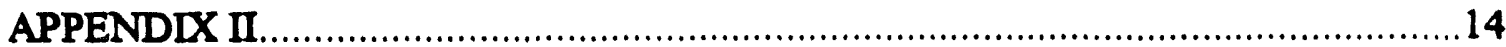

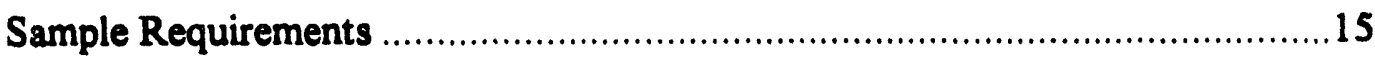

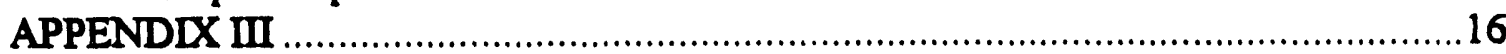

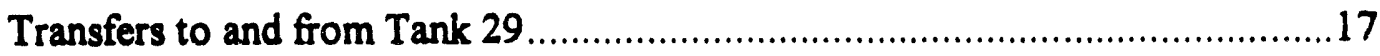

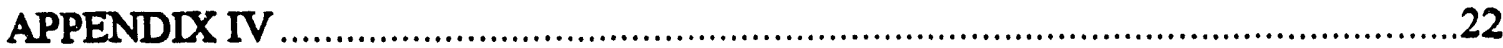

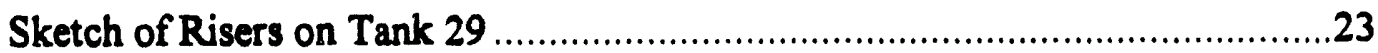

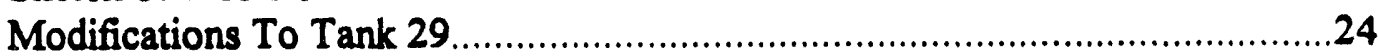

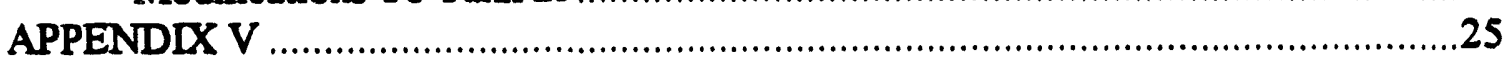

Active Permits Relating To Waste Removal ...........................................26

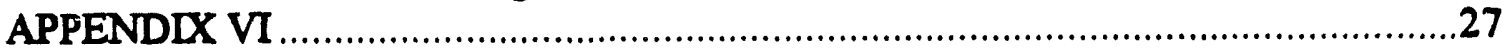

Analytical Results from Supernate Sample taken from Tank 29 on 11/23/92 _...28

Supernate Sample History Of Tank 29 ................................................29 


\section{INTRODUCTION}

Salt in Tank 29 will be dissolved to form a nearly saturated salt solution. The goal of Waste Removal is to remove the salt from the tank and deliver it to In-Tank Precipitation (ITP) at a concentration greater than 6.7 molar $\mathrm{Na}^{+}$(including dilution from transfer steam) to meet ITP requirements. (The amount of wash water used in ITP will be enough to dilute 6.7 molar $\mathrm{Na}^{+}$salt solution to 5 molar $\mathrm{Na}^{+}$required for the precipitation step.) The solution will be sent to In-Tank Precipitation (ITP) for precipitation of soluble cesium and strontium (radioactive elements). The precipitate will be transferred to the Defense Waste Processing Facility (DWPF) for final disposal. A USQD (Unreviewed Safety Question Determination) for criticality safety issue resolution will be completed prior to salt removal.

\section{SUMMARY}

This report outlines a plan for removing salt from Tank 29. The plan is based, in part, upon the experience gained in the removal of salt from Tank 19 and sludge from Tank 16. Tank 19 was the first tank in which slurry pumps were used during salt dissolution.

\section{DISCUSSION}

\section{History of Tank 29}

Tank 29 was constructed under project 981232 in a period from 1967 to $1970 .^{1}$ The first liquid fed to Tank 29 was 242-1H evaporator concentrate on September 20, 1971. Since then, only concentrate from evaporator $242-1 \mathrm{H}$ has been fed to Tank 29 except for a period in May and June of 1980 in which concentrated supernate was fed from Tank 10 to Tank 29. A list of all transfers to and from Tank 29 is printed in Appendix III. No sludge has been added to Tank 29.

\section{Comparison with Past Salt Removal Projects}

A demonstration of the use of slurry pumps for agitation during salt removal from Tank 19 took place in 1980 and $1981 .^{2}$ A comparison of factors relating to salt removal from Tank 19 and Tank 29 is given in Appendix I. Tank 16, containing sludge, is also included in the comparison, mainly because Tank 16 has cooling coils in connection with the use of slurry pumps.

To summarize the comparison, the rate of salt dissolution should be faster in Tank 29 than experienced in Tank 19 because Tank 19 used only one slurry pump (for the first three batches) and Tank 29 will use three slurry pumps for agitation. Also, there will be less dilution of the solution during agitation since leakage of bearing seal water into Tank 29 should be about 0.08 gpm per pump instead of $1.7 \mathrm{gpm}$. The reduction of in-leakage is due to improved seals on the pumps to be used on Tank 29. 


\section{EQUIPMENT}

The following equipment description assumes that all modifications planned for Tank 29 have been completed. If the thermowells cannot be removed and replaced, then the equipment may revert to that described in references 3 and 4. Appendix IV shows a sketch of the risers on Tank 29 and list modifications to Tank 29 in progress in preparation for salt removal.

The equipment needed for removal of salt from Tank 29 is currently being installed, modified or checked for operability. This includes three standard Slurry Pumps, a Transfer Jet (TJ) in riser $\mathrm{Cl}$ which will be replaced by a Telescoping Transfer Jet (TTJ) after some salt has been removed from the tank, the inhibited water makeup system, the tank ventilation system, and instruments to measure liquid temperature and liquid level.

Three Standard Slurry Pumps (Figure I), Bingham model \# VRP $2 \times 15$, will be installed in Risers E1, B6 and H. Each pump is 45 feet long. The pump drives are 150 horsepower motors without variable speed capability. The pumps discharge 1200 gallons per minute on a horizontal plane through two 1.5 inch discharge nozzles located on the impeller casing. The pumps are elevated by support spacers and located on turntables which can be rotated to aid in mixing fresh solution with salt crystals for faster salt dissolution. The pump shafts are supported by water lubricated bearings at intervals down the shaft. Burgmann mechanical seals are installed on the pump shafts to reduce seal water leakage into the tank. During pump operation, a positive pressure is maintained on the bearing seal water to prevent contaminated water from entering the bearing seal water system. Leaks through the bottom seal enter the HLW in the tank. A vent system forces any leakage out the top seal to enter the tank.

Instruments are available to record liquid level (by tape or conductivity), temperature at three different elevations, pressure in the tank, hydrogen concentration, radiation, and pressure drop through the exhaust gas filter systems.

Salt and supernate samples will be taken as required.

\section{DATA COLLECTION}

Appendix II lists some of the sample analyses required during salt dissolution from Tank 19. Many of the actinide analyses may be required to determine the potential for criticality during salt removal. For supernate fed to ITP, a Nuclear Criticality Safety Evaluation (NCSE) of the supernate will be required. ${ }^{5}$ The NCSE will determine the weight percent of equivalent U-235 that will be adsorbed on the sodium titanate particles from the supernate and will compare it to safe values. ITP6 and DWPF requirements must be checked at the time of sampling to make sure all the analytical requirements of these two groups are met.

The true value of data cannot be realized until it is put into a usable form. The report on Tank 19 salt dissolution was extremely valuable in preparation for salt removal from Tank 29 . The following data are important from the standpoint of development of plans for future salt removal from waste tanks. 


\section{Bingham Slurry Pump}

Provides agitation in $F$ and $H$ areas waste storage tanks to disolve ealt cake, alurry eludge and prepare feed for the DWPF. Three to four pumpe per tank.

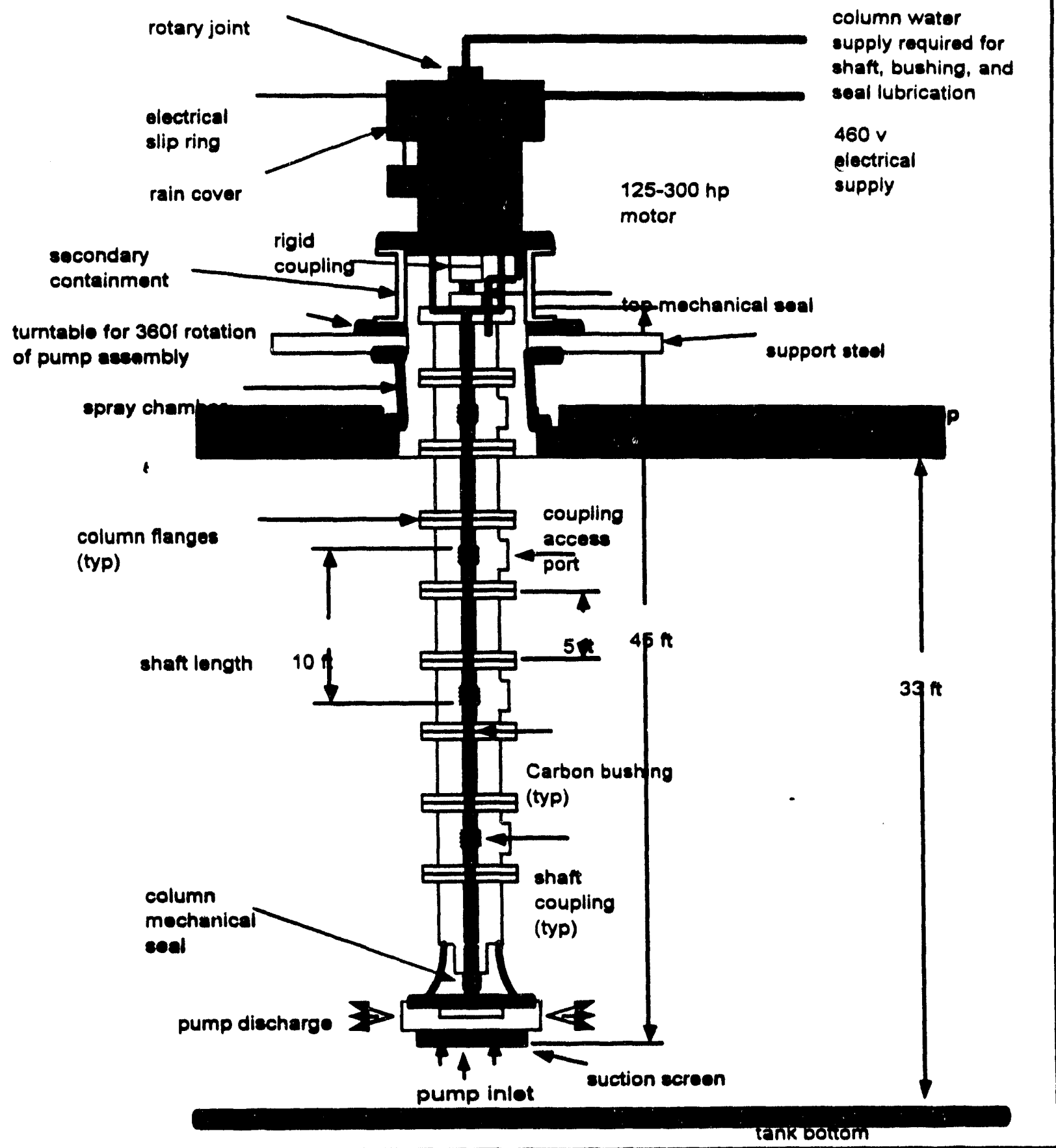

FIGURE I 
- The temperature of the supernate should be recorded and plotted versus time during use of the slurry pumps. Data should be included such as volume of supernate, how many slurry pumps were used, what amperage was used, and any problems or downtime on one or more pumps during slurrying operations. These data are needed because of the concern that the temperature of the supernate will rise too high and cause corrosion problems during salt dissolution. Given data of time versus temperature, future schedules can better estimate the time of agitation versus the temperature rise of the supernate when using three slurry pumps that have almost no leakage of bearing seal water into the tank.

- The density or specific gravity of the supernate versus time should be plotted. The primary purpose of the plot is to determine when to stop agitation. As the solution becomes saturated the specific gravity will level out to a horizontal line and further agitation will not increase the salt concentration. Given a plot of this data, the time to reach saturation can be estimated more accurately than using previous data when the slurry pump seals leaked. This data will be valuable in estimating schedules for future salt dissolution projects. The supernate in Tank 19 had lower specific gravities in each of four succeeding batches. The reason for the lower specific gravity in each batch is not known. Analytical data should be plotted against specific gravity for each sample. The specific gravity should be measured at the same temperature (preferably $77^{\circ} \mathrm{F}$ or $25^{\circ} \mathrm{C}$ ) for each sample.

- The time to' fill Tank 29 with the required inhibited solution should be recorded. This should include the time required to make up the solution as well as the time to add the solution to the tank.

- The transfer rate of solution from Tank 29 to Tank 48, at a specific steam pressure, from Tank 29 should be plotted against pressure head requirements as the tank level decreases. Record which pump (TJ or TTJ) was used for each transfer. Record the depth, from the bottom of the tank, of the inlet of the TJ or TTJ.

- An estimate of the amount of salt dissolved by the batch of inhibited water added per batch would be useful. The data should indicate the volume of salt removed, the volume of dissolving solution added, and the average specific gravity of each batch.. If caustic solution (about one molar $\mathrm{Na}+$ ) is added as the inhibited dissolving solution, the ratio of inhibited solution/salt dissolved should be higher than experienced in Tank 19 because the common ion lowers the solubility of salt.

- When the tank is nearly empty, a sample of the residual solids should be taken and analyzed. The solubility of the solids in water and oxalic acid should be determined. The actinide content of the solids should also be determined. Because Tank 29 will not be retired from service, the plans at this time are to empty the tank as much as possible without oxalic acid dissolution, unless a problem is associated with leaving the solids in the tank. A final decision must be made when data is available.

- Each sample of supernate should be recorded by chronological time of mixiig and the molarity of nitrate, nitrite, hydroxide, carbonate and sulfate should be plotted versus time. 
Given the supernate analysis and composition, an estimate of the salt dissolution rate can be made.

- The average rate of salt removal in gallons of salt removed per minute should be recorded. In Tank 19, the overall average, not counting downtime for repairs, analyses, etc., was about 7.5 gpm. In Tank 29, this rate should be improved by use of three slurry pumps that do not leak inhibited water through the bearing seals.

- A measurement of bearing water usage versus time should be recorded. The purpose of this data is to determine if the amount of in leakage into the tank through the bearings is increasing with time. The data will also point out a sudden failure of bearing seals if a rate of bearing water input is suddenly increased. The time should be noted when the slurry pumps are operating and also when they are not operating. This will help determine if there is any change in the rate of bearing water in-leakage when the pumps are operating versus not operating. Bearing water useage must be a continuous effort when the pumps are on.

- Any event that impacts the data requested above should be noted with the data.

\section{METHOD OF SAL C REMOVAL FROM TANK 29}

\section{General Methodology}

Prior to initiating any tasks outlined in this plan, all prerequisites for operation of equipment in Tank 29 must be implemented. Health Protection must be notified of all plans.

The following discussion of the method for salt removal is based on conditions in Tank 29 in October 1993. Until salt removal actually begins in a couple of years, modifications to Tank 29 are taking place to prepare the tank for salt dissolution and transfer (see Appendix IV). Liquid levels, temperatures, salt levels, etc., will change between now and when salt removal actually begins. Water will be added to the tank when equipment is removed from the risers and sprayed duing decontamination and removal (D \& R) activities. Since the tank is nearly full of liquid at this time, some supernate may have to be transferred from Tank 29 before salt removal is done. This document should be viewed as a living document and used for a guide to prepare the step by step activity list for salt removal from Tank 29.

The tank level on 5/5/93 was 354.2 inches. ${ }^{7}$ There are 69 inches of supernate above the salt level. The waste tank fill limit is 372 inches. ${ }^{8}$ The maximum operating limit is 362 inches. (ref. Procedure 241-H-140) Tank temperatures are taken at 78 inches from the bottom of the tank in riser D4, 222 inches in riser D4, the knuckle in riser A4 and also at the bottom of the tank. (ref. Sketch 138-9-H-55A) A new thermowell is scheduled to be installed into riser D4.

The first 62 inches of supernate transferred from Tank 29 to Tank 48 will have to be diluted about $1 / 1 \mathrm{vol} / \mathrm{vol}$ to reduce the $\mathrm{Na}^{+}$concentration before precipitation of radioactive isotopes. ${ }^{9}$ (62 inches represents the present liquid level, 354 inches, minus the level at the bottom of the TJ, 292 inches.) The supernate from a sample taken November 23, 1992, contained 14 molar $\mathrm{Na}+$ (see 
Appendix VI). Some dilution will take place during transfer when using the steam driven transfer jet. Sixty-nine (62) inches in Tank 29 equals about 217,000 gallons of supernate. Diluted 1/1, the volume in Tank 48 will be about 434,000 gallons. Tank 48 may already contain liquid depending upon the solution left in the tank after Tank 41 has been emptied. If so, then ITP will have to mix the liquid in Tank 48 and sample the liquid before a decision can be made on how much the solution in Tank 48 has to be diluted to meet the $\mathrm{Na}^{+}$specification. This will cause some delay in ITP processing during which salt can be dissolved in Tank 29. More supernate from salt dissolution in Tank 29 will probably be needed to make 600,000 gallons (which nominally represents one batch in Tank 48) of liquid within the specifications for ITP production.

The following steps for salt removal assume that the technical basis for criticality safety has been completed and documented in a Unreviewed Safety Question Determination (USQD).

The most likely scenario is that it will be acceptable to remove the supernate, but salt samples may be required when the supernate presently on top of the salt bed has been removed. Sampling and analysis of the results of the salt sample will interpose a delay in the resolution of the next step in the salt dissolution process. If criticality does pose a problem, water addition rates that limit the salt dissolution to a few inches per batch may be required. Other measures such as addition of neutron absorbers may even be required.

The steps in salt dissolution (assuming no criticality problems) are:

1. Transfer supernate from Tank 29 to Tank 48. Do not agitate the supernate with the slurry pumps before this first supernate transfer. The inlet to the Transfer Jet is presently located at the 292 inch level in Tank 29. Then 354-292 or 62 inches of liquid (about 217,000 gallons) is the maximum amount of supernate that can be removed initially. This solution, when diluted ( $1 \mathrm{vol} / 1 \mathrm{vol}$ ) in Tank 48 to lower the $\mathrm{Na}^{+}$concentration will make about 434,000 gallons of the initial batch for ITP to process.

From this point, about 166,000 gallons of five molar $\mathrm{Na}^{+}$solution will be needed in Tank 48 to finish making 600,000 gallons of salt solution for a batch. The suggested method for making the remaining solution is to add inhibited water into Tank 29 to the maximum operating level of 362 inches, agitate the supernate with the slurry pumps to obtain nearly saturated solution, sample the supernate to obtain the $\mathrm{Na}^{+}$content , and then calculate how much of this liquid to transfer to Tank 48 to make the remaining 166,000 gallons of five molar sodium solution after dilution. For example, if the supernate contained 10 molar $\mathrm{Na}^{+}$after salt dissolution, then 83,000 gallons $(166,000 / 2)$ of supernate could be transferred to Tank 48 and 83,000 gallons of wash water from Tank 22 could be added to Tank 48 to lower the sodium concentration.

Note: The amount of $\mathrm{OH}^{-}$in the dissolution water should be calculated, based on the salt analysis and an estimate of the amount of salt dissolved by the dissolution water. The correct amount of caustic (OH-) in the dissolution liquor should be the amount that will meet the Technical Standard in the salt solution formed. If the amount of caustic in the supernate is not enough to meet the Technical Standard 50\% caustic will have to be added 
to the tank. Since the salt is mostly sodium nitrate, a dissolving solution containing as high as 1.5 molar caustic could be needed to meet the Technical Standard. Two studies are being made which may affect this plan. SRTC is studying the Technical Standard to see if the amount of caustic needed to prevent corrosion can be reduced and whether or not caustic will be required in addition to dissolution water when dissolving salt. Systems Engineering will study the best way to add dissolution water to the waste tanks based on the SRTC recommendation, i.e. add caustic after the dissolution water has dissolved the salt or add caustic at the same time as the dissolution water using an in-line mixer. These studies will be done in 1994.)

A salt sample may be required by the HLW Engineering Support group before adding any inhibited water for salt dissolution. If so, the HLW Engineering Support group will require at least two weeks to study the results of the analyses for criticality concerns. This will cause a delay before inhibited water can be added.

[At issue is the time it takes to obtain the required analyses. Management should determine which laboratory will be responsible for the analytical work on the salt and supernate samples once the waste removal effort has begun. Experience to date has shown that several months were required to analyze a single salt sample from Tank 41. If the samples are not given top priority once waste removal has begun, the cost of waste removal will be enormous due to the delay.]

The following steps assume there is no criticality problem.

2. Add inhibited water to the 362 inch level to dissolve salt. (see note in 1 above about the inhibited water make-up.)

3. Ensure the reel tape has been raised to at least 10 inches above the liquid level and placed in "PARK". This will prevent alarms caused by agitation when the slurry pumps are turned on. Turn on the slurry pumps and rotate them to prevent damage to the cooling coils. ${ }^{10}$ The slurry pumps do not have a variable speed drive. Make sure the liquid level covers the slurry pumps enough to prevent high level alarms caused by mist formation and splashing.

While the slurry pumps are operating, check the supernate temperature and shut off the pumps if the temperature exceeds the operating limit.

4. Operate the slurry pumps for about 48 hours. Then shut off the slurry pumps and sample the supernate. If the $\mathrm{Na}^{+}$concentration is $6.7 \mathrm{M}$ or greater, prepare to transfer the supernate to Tank 48 .

[Note: There is no need to agitate the solution until it is completely saturated. The supernate will have to be diluted to about 5 molar $\mathrm{Na}+$ in Tank 48 before treating the solution to remove soluble isotopes. Some dilution of the salt solution (about 5 to $10 \%$ ) is experienced during transfer using the steam driven transfer jets. Make sure the steam 
pressure is near 150 psig so that the salt solution is not diluted too much during transfer from Tank 29 to Tank 48.]

If the solution does not contain at least 6 molar $\mathrm{Na}+$, then agitate the supernate another 48 hours using the slurry pumps and then take another sample.

5. Using the TJ, transfer the required amount of solution out of Tank 29 into Tank 48. Follow the logic in step 1 when removing the supernate.

Note: Step 6 will not be necessary until the TTJ is installed. There is no way to lower the liquid level to the salt level until the presently installed $\mathrm{TJ}$ is replaced by the TTJ.

6. Visually check the salt level and salt distribution in the tank after each supernate transfer out of Tank 29 except the first transfer. Check for undissolved salt hanging on the cooling coils or any other equipment above the liquid level. If a substantial amount of salt is left hanging on the equipment, then an action plan should be established to remove the salt before proceeding to a lower level in the tank.

7. Determine the salt level. If the salt level is above 215 inches in the tank, then add inhibited water to the 362 inch level and dissolve more salt. Continue the cyclic process (adding inhibited water to the 362 inch level and removing salt solution) until the salt level is below the 215 inch level. When the salt is below the 215 inch level, replace the TJ with the TTJ. The maximum level the TTJ can be retracted to is 215 inches $^{11}$.

8. Based on Tank 19 results, 2.4 gallons of water dissolved 1 gallon of salt, on the average. Using this ratio of dissolution water to salt dissolved, the dissolution water should be added to the full ( 362 inch) level for four times. The estimated salt dissolved for each batch will be:

$\begin{array}{cccc}\text { BATCH } & \text { ADD } & \text { DISSOLVE } & \text { NEW SALT LEVEL } \\ \text { First } & 5.8 \mathrm{ft} \text { water } & 2.4 \mathrm{ft} \mathrm{salt} & 265 \mathrm{in} . \\ \text { Second } & 8 \mathrm{ft} \text { water } & 3.3 \mathrm{ft} \mathrm{salt} & 226 \mathrm{in} . \\ \text { Third } & 11.2 \mathrm{ft} \text { water } & 4.7 \mathrm{ft} \mathrm{salt} & 169 \mathrm{in} . \\ \text { Fourth } & 15.9 \mathrm{ft} \text { water } & 6.6 \mathrm{ft} \mathrm{salt} & 90 \mathrm{in} . \\ \text { Fifth } & 7.5 \times 2.4=18 \mathrm{ft} & 7.5 \mathrm{ft} \mathrm{salt} & 0\end{array}$

After four batches, the salt level should be near the 90 inch level. When the salt level is below the 106 inch level, then add 2.4 times the salt level to the tank for the last batch. Note: The ratio of 2.4 is based on Tank 19 results. Some slight adjustment may be needed for Tank 29. The adjustment should be based on experience from the amount of salt dissolved in the first four batches. 
9. Lower the slirry pumps each time the salt level is reduced. It was shown in tank 19 that salt dissolved inuch fasier when the bottom of the slurry pump was close as possible to the salt. The pumps in Tank 29 can be lowered in increments of 2.5 feet.

10. After the fith batch, there may be some insoluble solids left in the bottom of the tank. Since Tank 29 will not be retired from service, there should be no need for chemical cleaning to completely empty the tank, unless a criticality problem exists. A sample of the solids left on the bottom of the tank should be taken and analyzed for solids incompatable with future use of the tank. The HIWE Waste Characterization Manager should be consulted to evaluate the sample results.

\section{Environmental Impacts}

All conditions of the applicable permits shall be met. A list of applicable permits is given in Appendix $V$. 
WSRC-TR-93-609

\section{REFERENCES}

1. Scaggs, R. A. HIW Programs Waste Digest, WER-HLE-931044, (June 11, 1993, p. 37)

2. A. Q. Goslen, "Tank 19 Salt Removal", DPSP-84-17-7, (August, 1986)

3. M. J. Mahoney, "Project S-3291 T,pe Three Tank Salt Removal, Phase I Tank 29 Riser Modifications", NMP-WPC\&I-90-4749, (November 8, 1990)

4. Goslen, A. Q., "Tank 29 Salt Removal Equipment Arrangement", NMP-WMT-901035, (December 5, 1990)

5. "Nuclear Criticality Safety Manual", WSRC-IM-93-13, Rev. 1 (July 1, 1993)

6. "Process Requirements for the In-Tank Precipitation Process (U)", WSRC-MM-91-63.

7. J. A. Pike, "Tank Chemistry Report, May 1993", WER-HLE-930230

8. "F- and H- Area High-Level Radioactive Waste Tank Farms", WSRC-RP-1044, Draft (12/04/92)

9. G. K. Georgeton and T. E. Pate, "Recommendations for Alternative ITP Feed", InterOffice Memorandum, (March 17, 1993)

10. P. J. Cahill, "Savannah River Plant Type III Tank Salt Removal, Phase I - S-3291 Tank 29H Deployable Cooling Coils", WCC-87-344, (July 22, 1987)

11. S. W. Holt, "Transfer Jet Heights for Tank 29 Waste Removal (Project 9S-3291), HLWWRP-93086, (August 3, 1993) ref in Item 7 p 7

12. W. L. West, "Tank 24 Salt Dissolution Plan", IOM, (May 13, 1981)

13. W. L. West, "Tank 16 Demonstration, Single-Pump Test Results", DPSP 79-17-12, (April 20, 1979)

14. D. T. Hobbs and C. J. Coleman, "Analysis of Tank 41H Saltcake Sample", WSRC-RP-93729, (May 12 1993) 
WSRC-TR-93-609

\section{APPENDIX I}

Difierences Between Tank 16 \& Tank 19 Experience And The Present Situation In Tank 29 
WSRC-TR-93-609

Differences Between Tank 16 \& Tank 19 Experience And The Present Situation In Tank 29

\begin{tabular}{|c|c|c|c|}
\hline Concern & Tank 16 & Tank 19 & Tank 29 \\
\hline $\begin{array}{l}\text { Damage to cooling } \\
\text { coils. }\end{array}$ & $\begin{array}{l}\text { Had cooling coils, but } \\
\text { sludge was only about } \\
24 \text { inches deep. } \\
\text { Sludge does not stick } \\
\text { to cooling coils like } \\
\text { salt does. No } \\
\text { comparison in this } \\
\text { area with Tank } 29 \text {. }\end{array}$ & No cooling coils. & $\begin{array}{l}\text { Salt is attached to } \\
\text { cooling coils. If salt is } \\
\text { not dissolved from the } \\
\text { top down, then the } \\
\text { weight of the salt could } \\
\text { damage the coils when } \\
\text { the liquid is removed } \\
\text { from the salt. A } \\
\text { maximum of five feet } \\
\text { of unsupported salt is } \\
\text { allowed on the coils. } 12 \\
\text { The cooling coils in } \\
\text { Tank } 29 \text { are suspended } \\
\text { from the top of the } \\
\text { tank, thereby causing } \\
\text { more concern for } \\
\text { damage. }\end{array}$ \\
\hline Agitation Pattern & $\begin{array}{l}\text { Single slurry pump } \\
\text { test showed } 30 \text { foot } \\
\text { radius agitation } \\
\text { pattern instead of } 20 \\
\text { foot radius pattern } \\
\text { predicted by TNX. }{ }^{13} \\
\text { Use of three slurry } \\
\text { pumps was sufficient } \\
\text { to slurry almost all of } \\
\text { the sludge from the } \\
\text { bottom of the tank. } \\
\end{array}$ & $\begin{array}{l}\text { Use of two slurry } \\
\text { pumps left some } \\
\text { undissolved solids in } \\
\text { the tank bottom even } \\
\text { with no coils in the } \\
\text { tank. Indicates that at } \\
\text { least three slurry } \\
\text { pumps are needed. }\end{array}$ & $\begin{array}{l}\text { Will use three slurry } \\
\text { pumps to promote salt } \\
\text { dissolution. The pump } \\
\text { will be basically the } \\
\text { same design as used in } \\
\text { Tank } 19 \text {, except for } \\
\text { better seals. }\end{array}$ \\
\hline Use of slurry pumps & $\begin{array}{l}\text { No experience here } \\
\text { for salt removal. }\end{array}$ & $\begin{array}{l}\text { One slurry pump until } \\
\text { last batch where two } \\
\text { slurry pumps were } \\
\text { used. Plenty of liquid } \\
\text { above the salt level at } \\
\text { the start of salt } \\
\text { dissolution. }\end{array}$ & $\begin{array}{l}\text { Three slurry pumps. } \\
\text { Liquid level above } \\
\text { pump suction will be } \\
\text { almost identical to the } \\
\text { Tank } 19 \text { experience. }\end{array}$ \\
\hline Criticality & $\begin{array}{l}\text { Sludge had excess Fe } \\
\text { and } \mathrm{Mn} \text {. }\end{array}$ & $\begin{array}{l}\text { Depleted U only. No } \\
\text { sample of residual } \\
\text { material. }\end{array}$ & $\begin{array}{l}\text { Will be documented in } \\
\text { USQD prior to salt } \\
\text { dissolution. }\end{array}$ \\
\hline
\end{tabular}


WSRC-TR-93-609

\begin{tabular}{|c|c|c|c|}
\hline $\begin{array}{l}\text { Dilution from slurry } \\
\text { pump seal in leakage. }\end{array}$ & $\begin{array}{l}\text { No experience } \\
\text { comparable with } \\
\text { Tank } 29 \text { situation. }\end{array}$ & $\begin{array}{l}\text { Average dilution from } \\
\text { slurry pump seal leaks } \\
\text { was } 1.7 \text { gallons per } \\
\text { minute. The second } \\
\text { batch took over } 600 \\
\text { hours to reach } \\
\text { saturation, partly } \\
\text { because of dilution. }\end{array}$ & $\begin{array}{l}\text { New pump seals } \\
\text { should leak very little, } \\
\text { i.e. only a few cubic } \\
\text { centimeters per minute. } \\
\text { Saturation should be } \\
\text { reached faster than } \\
\text { Tank } 19 \text { experienced. } \\
\text { Seal leakage to be } \\
\text { monitored. }\end{array}$ \\
\hline
\end{tabular}


WSRC-TR-93-609

APPENDIX II

Sample Requirements 


\section{Sample Requirements}

Salt Sample (Following outline of reference 14)

$$
\begin{aligned}
& { }^{233} \mathrm{U},{ }^{234} \mathrm{U},{ }^{235} \mathrm{U},{ }^{236} \mathrm{U},{ }^{238} \mathrm{U} \text {, TOTAL } \mathrm{U} \\
& { }^{239} \mathrm{Pu},{ }^{240} \mathrm{Pu},{ }^{241} \mathrm{Pu},{ }^{242} \mathrm{Pu} \text {, TOTAL } \mathrm{Pu}
\end{aligned}
$$

Determine the water soluble and water insoluble Plutonium and Uranium.

Ag, As, Se, Ca, Cd, Co, Cu, Mg, Mn, Pb, Zn, Zr, Al, Ba, Fe, La, Li, Mo, Na, Ni, Sn, Sr, $\mathrm{Tc}, \mathrm{Ti}, \mathrm{V}, \mathrm{B}, \mathrm{Cr}, \mathrm{P}, \mathrm{Si}, \mathrm{K}, \mathrm{Hg}, \mathrm{U}, \mathrm{Pu}$ (both soluble and insoluble of all in this list)

Dissolution tests as indicated in reference 14 may also be required. Check with High Level Waste Engineering Support Manager.

\section{Supernate Liquid Sample}

The supernate sample is of interest to ITP, Engineering, and HLWE Engineering Support. Check with each group for completeness of the analytical requirements before sampling. The following analyses are required at the present time.

sp. gr., $\mathrm{NO}_{3}, \mathrm{NO}_{2}, \mathrm{OH}, \mathrm{CO}_{3}, \mathrm{SO}_{4}, \mathrm{pH}$, soluble $\mathrm{U}$ and soluble $\mathrm{Pu}$ in the isotopes listed in the salt sample. 
WSRC-TR-93-609

\section{APPENDIX III}

\section{Transfers to and from Tank 29}

Compiled from WSRC-TR-93-425, Waste Transfers and Miscellaneous Additions (U), August 9, 1993 
WSRC-TR-93-609

Transfers to and from Tank 29

\begin{tabular}{|c|c|c|c|c|c|c|c|c|}
\hline $\begin{array}{l}\text { Reportad } \\
\text { Dete }\end{array}$ & $\begin{array}{l}\text { Actued } \\
\text { Date }\end{array}$ & $\begin{array}{c}\text { Pecoipt } \\
\text { Tenk }\end{array}$ & $\begin{array}{c}\text { Sending } \\
\text { Tank }\end{array}$ & $\begin{array}{l}\text { Sonding } \\
\text { (gal) }\end{array}$ & $\begin{array}{c}\text { Recoipt } \\
\text { lgall }\end{array}$ & Slu & Type Weste & Description/Commente \\
\hline Sep-71 & $9 / 20 / 71$ & 29 & $242-1 \mathrm{H}$ & 299000 & 299000 & 0 & EVAPCONC & \\
\hline Sep-71 & $9 / 20 / 71$ & 32 & 29 & 21000 & 21000 & 0 & CONC & Start-up Heel for Tank 32 \\
\hline Oct-71 & $10 / 20 / 71$ & 29 & $242-1 \mathrm{H}$ & 225000 & 225000 & 0 & EVAPCONC & \\
\hline Nov-71 & $11 / 20 / 71$ & 29 & $242.1 \mathrm{H}$ & 304000 & 304000 & 0 & EVAPCONC & \\
\hline Dec-71 & $12 / 20 / 71$ & 29 & $242-1 \mathrm{H}$ & 394000 & 394000 & 0 & EVAPCONC & \\
\hline $\operatorname{Jan}-72$ & $12 / 29 / 71$ & 21 & 29 & 20000 & 21000 & 0 & CONCSN & \\
\hline $\operatorname{Jan}-72$ & $1 / 1 / 72$ & 21 & 29 & 57000 & 60000 & 0 & CONCSN & \\
\hline $\operatorname{Jan}-72$ & $1 / 9 / 72$ & 21 & 29 & 625000 & 648000 & 0 & CONCSN & \\
\hline $\operatorname{Jan}-72$ & $1 / 20 / 72$ & 29 & $242-1 \mathrm{H}$ & 240000 & 240000 & 0 & EVAPCONC & \\
\hline Feb-72 & $2 / 20 / 72$ & 10 & 29 & 90000 & 90000 & 0 & EDT & \\
\hline Feb-72 & $2 / 20 / 72$ & 29 & $242-1 \mathrm{H}$ & 319000 & 319000 & 0 & EVAPCONC & \\
\hline Mar-72 & $3 / 20 / 72$ & 29 & $242-1 \mathrm{H}$ & 250000 & 250000 & 0 & EVAPCONC & \\
\hline Apr-72 & $4 / 6 / 72$ & 21 & 29 & 80000 & 82000 & 0 & CONCSN & \\
\hline Apr-72 & $4 / 20 / 72$ & 29 & $242-1 \mathrm{H}$ & 88000 & 88000 & 0 & EVAPCONC & \\
\hline May -72 & $5 / 20 / 72$ & 29 & $242-1 \mathrm{H}$ & 32000 & 32000 & 0 & EVAPCONC & \\
\hline Jun-72 & $6 / 20 / 72$ & 29 & & 0 & 4000 & 0 & MISCADD/TRAN & Cond. H20 from CTS System \\
\hline Jun-72 & $6 / 20 / 72$ & 29 & $242-1 \mathrm{H}$ & 21000 & 21000 & 0 & EVAPCONC & \\
\hline Jul-72 & $7 / 4 / 72$ & 21 & 29 & 635000 & 651000 & 0 & CONCSN & \\
\hline Jul-72 & $7 / 17 / 72$ & 21 & 29 & 329000 & 336000 & 0 & CONCSN & \\
\hline $\mathrm{Jul}-72$ & $7 / 20 / 72$ & 29 & & 0 & 4000 & 0 & MISCADD/TRAN & Cond. $\mathrm{H}_{2} \mathrm{O}$ from Cls System \\
\hline Aug-72 & $8 / 20 / 72$ & 29 & & 0 & 4000 & 0 & MISCADD/TRAN & Cond. $\mathrm{H} 2 \mathrm{O}$ from CTS System \\
\hline Aug-72 & $8 / 20 / 72$ & 29 & $242-1 H$ & 376000 & 376000 & 0 & EVAPCONC & \\
\hline Sep- 72 & $9 / 20 / 72$ & 29 & & 0 & 4000 & 0 & MISCADD/TRAN & Cond. $\mathrm{H} 2 \mathrm{O}$ from CTS System \\
\hline Sep-72 & $9 / 20 / 72$ & 29 & $242-1 \mathrm{H}$ & 177000 & 177000 & 0 & EVAPCONC & \\
\hline Oct-72 & $10 / 20 / 72$ & 29 & & 0 & 4000 & 0 & MISCADD/TRAN & Cond. $\mathrm{H} 2 \mathrm{O}$ from CTS System \\
\hline Oct-72 & $10 / 20 / 72$ & 29 & $242-1 H$ & 280000 & 280000 & 0 & EVAPCONC & \\
\hline Nov-72 & $11 / 20 / 72$ & 29 & & 0 & 4000 & 0 & MISCADD/TRAN & Cond. H2O from CTS System \\
\hline Nov- 72 & $11 / 20 / 72$ & 29 & $242-1 \mathrm{H}$ & 165000 & 165000 & 0 & EVAPCONC & \\
\hline Dec-72 & $12 / 19 / 72$ & 21 & 29 & 8000 & 9000 & 0 & CONCSN & \\
\hline Dec-72 & $12 / 20 / 72$ & 29 & & 0 & 4000 & 0 & MISCADD/TRAN & Cond. $\mathrm{H} 2 \mathrm{O}$ from CTS System \\
\hline Jan-73 & $1 / 4 / 73$ & 21 & 29 & 86000 & 89000 & 0 & CONCSN & \\
\hline $\operatorname{Jan}-73$ & $1 / 13 / 73$ & 21 & 29 & 520000 & 536000 & 0 & CONCSN & \\
\hline $\operatorname{Jan}-73$ & $1 / 20 / 73$ & 29 & & 0 & 4000 & 0 & MISCADD/TRAN & Cond. Water from CTS \\
\hline Feb-73 & $2 / 17 / 73$ & 21 & 29 & 468000 & 486000 & 0 & HHWCONCSN & \\
\hline Feb-73 & $2 / 20 / 73$ & 29 & & 0 & 4000 & 0 & MISCADD/TRAN & Cond. Water from CTS \\
\hline Mar-73 & $3 / 20 / 73$ & 29 & & 0 & 3000 & 0 & MISCADD/TRAN & Cond. Water from CTS \\
\hline Mar-73 & $3 / 20 / 73$ & 29 & $242-1 \mathrm{H}$ & 306000 & 306000 & 0 & EVAPCONC & \\
\hline Apr. 73 & $4 / 20 / 73$ & 29 & & 0 & 5000 & 0 & MISCADD/TRAN & Cond. Water from CTS \\
\hline Apr-73 & $4 / 20 / 73$ & 29 & $242-1 \mathrm{H}$ & 297000 & 297000 & 0 & EVAPCONC & \\
\hline May-73 & $5 / 20 / 73$ & 29 & & 0 & 5000 & 0 & MISCADD/TRAN & Cond. Water from CTS \\
\hline May-73 & $5 / 20 / 73$ & 29 & $242-1 \mathrm{H}$ & 268000 & 268000 & 0 & EVAPCONC & \\
\hline Jun-73 & $6 / 20 / 73$ & 29 & & 0 & 4000 & 0 & MISCADD/TRAN & Cond. Water from CTS \\
\hline Jun-73 & $6 / 20 / 73$ & 29 & $242-1 \mathrm{H}$ & 69000 & 69000 & 0 & EVAPCONC & \\
\hline Jul-73 & $7 / 13 / 73$ & 21 & 29 & 131000 & 135000 & 0 & CONCSN & \\
\hline Jul.73 & $7 / 20 / 73$ & 29 & & 0 & 5000 & 0 & MISCADD/TRAN & Cond. Water from CTS \\
\hline Jul-73 & $7 / 20 / 73$ & 29 & $242-1 \mathrm{H}$ & 30000 & 30000 & 0 & EVAPCONC & \\
\hline Aug -73 & $7 / 26 / 73$ & 21 & 29 & 84000 & 88000 & 0 & CONCSN & \\
\hline
\end{tabular}




\begin{tabular}{|c|c|c|c|c|c|c|c|c|}
\hline Aug-73 & $7 / 30 / 73$ & 21 & 29 & 319000 & 335000 & 0 & CONCSN & \\
\hline Aug-73 & $8 / 12 / 73$ & 21 & 29 & 161000 & 169000 & 0 & CONCSN & \\
\hline Aug. 73 & $8 / 20 / 73$ & 29 & & 0 & 5000 & 0 & MIS SADD/TRAN & Cond. Water from CTS \\
\hline Aug-73 & $8 / 20 / 73$ & 29 & $242-1 \mathrm{H}$ & 299000 & 299000 & 0 & EVADCONC & \\
\hline Sep-73 & $9 / 6 / 73$ & 21 & 29 & 534000 & 561000 & 0 & $\mathrm{CO}, \overline{\mathrm{CSN}}$ & \\
\hline Sep-73 & $9 / 20 / 73$ & 29 & & 0 & 4000 & 0 & MISCADD/TRAN & Cond. Water from CTS \\
\hline Sep-73 & $9 / 20 / 73$ & 29 & & 0 & 3000 & 0 & MISCADD/TRAN & CRC Flushes \\
\hline Sep-73 & $9 / 20 / 73$ & 29 & $242.1 \mathrm{H}$ & 524000 & 524000 & 0 & EVAPCONC & \\
\hline Oct-73 & $10 / 8 / 73$ & 21 & 29 & 400000 & 419000 & 0 & CONCSN & \\
\hline Oct-73 & $10 / 20 / 73$ & 29 & & 0 & 4000 & 0 & MISCADD/TRAN & Cond. Water from CTS \\
\hline Oct-73 & $10 / 20 / 73$ & 29 & $242.1 \mathrm{H}$ & 590000 & 590000 & 0 & EVAPCONC & \\
\hline Nov-73 & $11 / 4 / 73$ & 21 & 29 & 287000 & 301000 & 0 & CONCSN & \\
\hline Nov-73 & $11 / 20 / 73$ & 29 & & 0 & 5000 & 0 & MISCADD/TRAN & Conde. Water from CTS \\
\hline Nov-73 & $11 / 20 / 73$ & 29 & $242-1 \mathrm{H}$ & 191000 & 191000 & 0 & EVAPCONC & \\
\hline Dec-73 & $12 / 20 / 73$ & 29 & & 0 & 2000 & 0 & MISCADD/TRAN & Cond. Water from CTS \\
\hline Dec- 73 & $12 / 20 / 73$ & 29 & $242-1 \mathrm{H}$ & 261000 & 261000 & 0 & EVAPCONC & \\
\hline $\operatorname{Jan}-74$ & $12 / 28 / 73$ & 21 & 29 & 196000 & 206000 & 0 & CONCSN & \\
\hline Jan-74 & $1 / 4 / 74$ & 21 & 29 & 353000 & 370000 & 0 & CONCSN & \\
\hline Jan-74 & $1 / 20 / 74$ & 29 & & 0 & 5000 & 0 & MISCADD/TRAN & CTS Condensation \\
\hline $\operatorname{Jan}-74$ & $1 / 20 / 74$ & 29 & $242-1 \mathrm{H}$ & 176000 & 176000 & 0 & EVAPCONC & \\
\hline Feb-74 & $2 / 20 / 74$ & 29 & $242-1 \mathrm{H}$ & 353000 & 353000 & 0 & & \\
\hline Mar-74 & $3 / 10 / 74$ & 21 & 29 & 406000 & 422000 & 0 & CONCSN & \\
\hline Apr-74 & $4 / 5 / 74$ & 21 & 29 & 333000 & 349000 & 0 & CONCSN & \\
\hline Apr-74 & $4 / 20 / 74$ & 29 & $242.1 \mathrm{H}$ & 363000 & 393000 & 0 & EVAPCONC & \\
\hline May-74 & $4 / 27 / 74$ & 21 & 29 & 258000 & 271000 & 0 & CONCSN & \\
\hline May-74 & $5 / 20 / 74$ & 21 & 29 & 289000 & 304000 & 0 & CONCSN & \\
\hline May-74 & $5 / 20 / 74$ & 29 & $242-1 \mathrm{H}$ & 674000 & 695000 & 0 & EVAPCONC & \\
\hline Jun-74 & $5 / 29 / 74$ & 21 & 29 & 431000 & 453000 & 0 & CONCSN & \\
\hline Jun-74 & $6 / 18 / 74$ & 21 & 29 & 201000 & 211000 & 0 & CONCSN & \\
\hline Jun-74 & $6 / 20 / 74$ & 29 & $242-1 \mathrm{H}$ & 677000 & 713000 & 0 & EVAPCONC & \\
\hline Jul-74 & $7 / 20 / 74$ & 29 & $242-1 \mathrm{H}$ & 188000 & 188000 & 0 & EVAPCONC & \\
\hline Aug-74 & $8 / 1 / 74$ & 21 & 29 & 662000 & 695000 & 0 & CONCSN & \\
\hline Aug. 74 & $8 / 20 / 74$ & 21 & 29 & 267000 & 280000 & 0 & CONCSN & \\
\hline Aug-74 & $8 / 20 / 74$ & 29 & $242-1 \mathrm{H}$ & 502000 & 555000 & 0 & EVAPCONC & \\
\hline Sep-74 & $8 / 25 / 74$ & 21 & 29 & 221000 & 232000 & 0 & CONCSN & \\
\hline Sep-74 & $9 / 11 / 74$ & 21 & 29 & 294000 & 309000 & 0 & CONCSN & \\
\hline Sep-74 & $9 / 16 / 74$ & 21 & 29 & 140000 & 147000 & 0 & CONCSN & \\
\hline Sep-74 & $9 / 20 / 74$ & 29 & $242-1 \mathrm{H}$ & 765000 & 810000 & 0 & EVAPCONC & \\
\hline Oct-74 & $9 / 24 / 74$ & 21 & 29 & 222000 & 233000 & 0 & CONCSN & \\
\hline Oct-74 & $10 / 20 / 74$ & 29 & $242-1 \mathrm{H}$ & 228000 & 244000 & 0 & EVAPCONC & \\
\hline Nov-74 & $11 / 9 / 74$ & 21 & 29 & 578000 & 607000 & 0 & CONC & \\
\hline Nov-74 & $11 / 20 / 74$ & 29 & $242-1 \mathrm{H}$ & 246000 & 264000 & 0 & EVAPCONC & \\
\hline Dec-74 & $12 / 20 / 74$ & 29 & $242-1 \mathrm{H}$ & 433000 & 467000 & 0 & EVAPCONC & \\
\hline Jun-75 & $6 / 8 / 75$ & 21 & 29 & 123000 & 129000 & 0 & HHW & \\
\hline Jul-75 & $7 / 10 / 75$ & 21 & 29 & 76000 & 800000 & 0 & CONCSN & \\
\hline Jul-75 & $7 / 14 / 75$ & 21 & 29 & 325000 & 341000 & 0 & CONCSN & \\
\hline Nov-75 & $11 / 20 / 75$ & 29 & $242-1 \mathrm{H}$ & 493000 & 493000 & 0 & EVAPCONC & \\
\hline Dec-75 & $12 / 20 / 75$ & 29 & $242-1 \mathrm{H}$ & 17000 & 17000 & 0 & EVAPCONC & \\
\hline Mar-76 & $3 / 20 / 76$ & 29 & 242-11 & 278000 & 295000 & 0 & EVAPCONC & \\
\hline Mar-76 & $2 / 25 / 76$ & 13 & 29 & 225000 & 237000 & 0 & HHWCONCSN & \\
\hline Mar-76 & 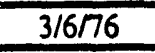 & 13 & 29 & 147000 & 154000 & 0 & HHWCONCSN & \\
\hline Apr-76 & $4 / 20 / 76$ & 29 & $242-1 \mathrm{H}$ & 205000 & 205000 & 0 & EVAPCONC & \\
\hline
\end{tabular}




\begin{tabular}{|c|c|c|c|c|c|c|c|c|}
\hline Apr-76 & $4 / 12 / 76$ & 13 & 29 & 265000 & 278000 & 0 & HHWCONCSN & \\
\hline May-76 & $5 / 20 / 76$ & 29 & $242-1 \mathrm{H}$ & 68000 & 68000 & 0 & EVAPCONC & \\
\hline Jun-76 & $6 / 20 / 76$ & 13 & 29 & 186000 & 195000 & 0 & HHWCONC & \\
\hline Jul-76 & $7 / 20 / 76$ & 29 & $242.1 \mathrm{H}$ & 151000 & 151000 & 0 & EVAPCONC & \\
\hline Jul. 76 & $6 / 24 / 76$ & 13 & 29 & 117000 & 122000 & 0 & HHWCONCSN & \\
\hline Aug-76 & $8 / 20 / 76$ & 29 & $242-1 \mathrm{H}$ & 171000 & 181000 & 0 & EVAPCONC & \\
\hline Sep-76 & $9 / 4 / 76$ & 13 & 29 & 143000 & 149000 & 0 & HHWCONCSN & \\
\hline Oct-76 & $10 / 20 / 76$ & 29 & $242-1 \mathrm{H}$ & 137000 & 137000 & 0 & EVAPCONC & \\
\hline Feb-77 & $2 / 5 / 77$ & 13 & 29 & 205000 & 212000 & 0 & CONCSN & \\
\hline Mar-77 & $3 / 20 / 77$ & 29 & $242-1 \mathrm{H}$ & 229000 & 239000 & 0 & EVAPCONC & \\
\hline May- 77 & $5 / 13 / 77$ & 13 & 29 & 111000 & 116000 & 0 & SNATE & \\
\hline May- -77 & $5 / 20 / 77$ & 29 & $242-1 \mathrm{H}$ & 46000 & 47000 & 0 & EVAPCONC & \\
\hline Jun-77 & $6 / 6 / 77$ & 13 & 29 & 49000 & 51000 & 0 & CONCSN & \\
\hline Jun-77 & $6 / 20 / 77$ & 29 & $242-1 \mathrm{H}$ & 84000 & 84000 & 0 & EVAPCONC & \\
\hline Sep-77 & $9 / 10 / 77$ & 13 & 29 & 284000 & 295000 & 0 & CONCSN & \\
\hline Sep-77 & $9 / 20 / 77$ & 29 & $242-1 \mathrm{H}$ & 24000 & 24000 & 0 & EVAPCONC & \\
\hline Oct- 77 & $10 / 4 / 77$ & 13 & 29 & 39000 & 42000 & 0 & CONCSN & \\
\hline Oct-77 & $10 / 20 / 77$ & 29 & $242-1 \mathrm{H}$ & 298000 & 307000 & 0 & EVAPCONC & \\
\hline $\operatorname{Jan}-78$ & $12 / 31 / 77$ & 36 & 29 & 241000 & 250000 & 0 & CONCSN & \\
\hline $\operatorname{Jan}-78$ & $1 / 20 / 78$ & 29 & $242-1 \mathrm{H}$ & 15000 & 32000 & 0 & EVAPCONC & \\
\hline Feb-78 & $2 / 20 / 78$ & 29 & $242-1 \mathrm{H}$ & 207000 & 214000 & 0 & EVAPCONC & \\
\hline Mar-78 & $3 / 13 / 78$ & 37 & 29 & 238000 & 250000 & 0 & CONCSN & \\
\hline Apr-78 & $4 / 20 / 78$ & 29 & $242-1 \mathrm{H}$ & 3000 & 3000 & 0 & EVAPCONC & \\
\hline May-78 & $5 / 20 / 78$ & 29 & $242-1 \mathrm{H}$ & 30000 & 30000 & 0 & EVAPCONC & \\
\hline Jun-78 & $6 / 20 / 78$ & 37 & 29 & 49000 & 51000 & 0 & CONCSN & \\
\hline Jun-78 & $6 / 20 / 78$ & 29 & $242-1 \mathrm{H}$ & 201000 & 201000 & 0 & EVAPCONC & \\
\hline Jul-78 & $6 / 22 / 78$ & 37 & 29 & 186000 & 194000 & 0 & CONCSN & \\
\hline Jul-78 & $7 / 19 / 78$ & 36 & 29 & 9000 & 9000 & 0 & CONCSN & \\
\hline Jul-78 & $7 / 20 / 78$ & 29 & $242-1 \mathrm{H}$ & 234000 & 247000 & 0 & EVAPCONC & \\
\hline Aug-78 & $7 / 24 / 78$ & 36 & 29 & 229000 & 238000 & 0 & CONCSN & \\
\hline Aug-78 & $8 / 20 / 78$ & 29 & $242-1 \mathrm{H}$ & 138000 & 138000 & 0 & EVAPCONC & \\
\hline Sep-78 & $9 / 6 / 78$ & 36 & 29 & 212000 & 221000 & 0 & HHWCONCSN & \\
\hline Sep-78 & $9 / 20 / 78$ & 29 & $242-1 \mathrm{H}$ & 113000 & 113000 & 0 & EVAPCONC & \\
\hline Nov-78 & $11 / 20 / 78$ & 29 & $242-1 \mathrm{H}$ & 179000 & 179000 & 0 & EVAPCONC & \\
\hline Dec-78 & $11 / 23 / 78$ & 37 & 29 & 242000 & 252000 & 0 & CONCSN & \\
\hline Dec-78 & $12 / 20 / 78$ & 29 & $242-1 \mathrm{H}$ & 211000 & 211000 & 0 & EVAPCONC & \\
\hline $\operatorname{Tan}-79$ & $1 / 19779$ & 37 & 29 & 247000 & 261000 & 0 & CONCSN & \\
\hline Jan-79 & $1 / 19779$ & 35 & 29 & 2000 & 2000 & 0 & CONCSN & \\
\hline Jan-79 & $1 / 20 / 79$ & 29 & $242-1 \mathrm{H}$ & 62000 & 62000 & 0 & EVAPCONC & \\
\hline Feb-79 & $2 / 19 / 79$ & 36 & 29 & 247000 & 256000 & 0 & CONCSN & \\
\hline Feb-79 & $2 / 19 / 79$ & 35 & 29 & 2000 & 2000 & 0 & CONCSN & \\
\hline Feb.79 & $2 / 20 / 79$ & 29 & $242-1 H$ & 237000 & 237000 & 0 & EVAPCONC & \\
\hline Mar-79 & $3 / 20 / 79$ & 36 & 29 & 36000 & 37000 & 0 & CONCSN & \\
\hline Mar-79 & $3 / 20 / 79$ & 35 & 29 & 2000 & 2000 & 0 & CONCSN & \\
\hline Mar-79 & $3 / 20 / 79$ & 29 & $242-1 \mathrm{H}$ & 234000 & 243000 & 0 & EVAPCONC & \\
\hline Apr-79 & $3 / 22 / 79$ & 36 & 29 & 144000 & 148000 & 0 & CONCSN & \\
\hline Apt-79 & $3 / 23 / 79$ & 37 & 29 & 42000 & 43000 & 0 & CONCSN & \\
\hline Apr-79 & $4 / 20 / 79$ & 37 & 29 & 121000 & 125000 & 0 & CONCSN & \\
\hline Apt-79 & $4 / 20 / 79$ & 35 & 29 & 2000 & 2000 & 0 & CONCSN & \\
\hline Apr. -79 & $4 / 20 / 79$ & 29 & $242-1 \mathrm{H}$ & 225000 & 225000 & 0 & EVAPCONC & \\
\hline May-79 & $4 / 22 / 79$ & 37 & 29 & 119000 & 123000 & 0 & CONCSN & \\
\hline May-79 & $5 / 17 / 79$ & 36 & 29 & 126000 & 129000 & 0 & CONCSN & \\
\hline
\end{tabular}


WSRC-TR-93-609

\begin{tabular}{|c|c|c|c|c|c|c|c|c|}
\hline May-79 & $5 / 17 / 79$ & 13 & 29 & 8000 & 9000 & 0 & CONCSN & \\
\hline May-79 & $5 / 18 / 79$ & 13 & 29 & 52000 & 6000 & 0 & CONCSN & \\
\hline May-79 & $5 / 18 / 79$ & 37 & 29 & 6000 & 54000 & 0 & CONCSN & \\
\hline May-79 & $5 / 20 / 79$ & 29 & $242-1 \mathrm{H}$ & 214000 & 226000 & 0 & EVAPCONC & \\
\hline May-80 & $5 / 2 / 80$ & 29 & 10 & 15176 & 52345 & 0 & CONCSN & \\
\hline May-80 & $5 / 13 / 80$ & 29 & 10 & 3523 & 8387 & 0 & CONCSN & \\
\hline May-80 & $5 / 14 / 80$ & 29 & 10 & 4607 & 16195 & 0 & CONCSN & \\
\hline May-80 & $5 / 15 / 80$ & 29 & 10 & 4336 & 15328 & 0 & CONCSN & \\
\hline May-80 & $5 / 20 / 80$ & 29 & 10 & 5420 & 53962 & 0 & CONCSN & \\
\hline Jun-80 & $5 / 24 / 80$ & 29 & 10 & 16100 & 16100 & 0 & CONCSN & \\
\hline Jun-80 & $5 / 25 / 80$ & 29 & 10 & 15100 & 16300 & 0 & CONCSN & \\
\hline Jun-80 & $5 / 27 / 80$ & 29 & 10 & 14600 & 14700 & 0 & CONCSN & \\
\hline Jun-80 & $6 / 1 / 80$ & 37 & 29 & 26000 & 27000 & 0 & CONCSN & \\
\hline Jun-80 & $6 / 6 / 80$ & 29 & 10 & 4600 & 3000 & 0 & CONCSN & \\
\hline Jun-80 & $6 / 9 / 80$ & 29 & 10 & 5400 & 6900 & 0 & $\overline{C O N C S N}$ & \\
\hline Jun-80 & $6 / 10 / 80$ & 29 & 10 & 7600 & 7700 & 0 & CONCSN & \\
\hline Jun-80 & $6 / 11 / 80$ & 29 & 10 & 7300 & 5600 & 0 & CONCSN & \\
\hline Jun-80 & $6 / 12 / 80$ & 29 & 10 & 7300 & 7400 & 0 & CONCSN & \\
\hline Nov-80 & $10 / 31 / 80$ & 37 & 29 & 156000 & 164000 & 0 & CONSN & \\
\hline Nov-80 & $11 / 20 / 80$ & 29 & $242-1 \mathrm{H}$ & 218000 & 241000 & 0 & EVAPCONC & \\
\hline Dec-80 & $11 / 28 / 80$ & 36 & 29 & 218000 & 230000 & 0 & CONCSN & \\
\hline Dec-80 & $12 / 18 / 80$ & 36 & 29 & 157000 & 174000 & 0 & CONCSN & \\
\hline Dec-80 & $12 / 20 / 80$ & 29 & $242-1 \mathrm{H}$ & 215000 & 215000 & 0 & EVAPCONC & \\
\hline $\operatorname{Jan}-81$ & $12 / 24 / 80$ & 37 & 29 & 92000 & 92000 & 0 & CONCSN & \\
\hline Jan-81 & $1 / 20 / 81$ & 29 & $242-1 \mathrm{H}$ & 185000 & 210000 & 0 & EVAPCONC & \\
\hline Feb-81 & $1 / 22 / 81$ & 37 & 29 & 186000 & 190000 & 0 & CONCSN & \\
\hline Feb-81 & $1 / 25 / 81$ & 37 & 29 & 82000 & 86000 & 0 & CONCSN & \\
\hline Feb-81 & $2 / 20 / 81$ & 29 & $242-1 \mathrm{H}$ & 190000 & 231000 & 0 & EVAPCONC & \\
\hline Mar-81 & $3 / 5 / 81$ & 37 & 29 & 179000 & 187000 & 0 & CONCSN & \\
\hline Mar-81 & $3 / 20 / 81$ & 36 & 29 & 158000 & 168000 & 0 & CONCSN & \\
\hline Mar-81 & $3 / 20 / 81$ & 29 & $242-1 \mathrm{H}$ & 106000 & 130000 & 0 & EVAPCONC & \\
\hline Apr-81 & $4 / 20 / 81$ & 29 & $242-1 \mathrm{H}$ & 201000 & 221000 & 0 & EVAPCONC & \\
\hline May-81 & $4 / 22 / 81$ & 37 & 29 & 22000 & 24000 & 0 & CONCSN & \\
\hline May-81 & $5 / 1 / 81$ & 37 & 29 & 184000 & 198000 & 0 & CONCSN & \\
\hline May-81 & $5 / 20 / 81$ & 29 & $242-1 \mathrm{H}$ & 144000 & 169000 & 0 & EVAPCONC & \\
\hline Nov-81 & $11 / 15 / 81$ & 37 & 29 & 192000 & 196000 & 0 & CONCSN & \\
\hline Mar-82 & $3 / 11 / 82$ & 36 & 29 & 203000 & 211000 & 0 & CONCSN & \\
\hline Mar-82 & $3 / 20 / 82$ & 29 & $242-1 \mathrm{H}$ & 290000 & 290000 & 0 & EVAPCONC & \\
\hline Apt-82 & $3 / 29 / 82$ & 36 & 29 & 179000 & 186000 & 0 & SNATE & \\
\hline Apr-82 & $4 / 20 / 82$ & 29 & $242-1 \mathrm{H}$ & 82000 & 94000 & 0 & EVAPCONC & \\
\hline Jul-82 & $7 / 16 / 82$ & 36 & 29 & 190000 & 223000 & 0 & CONCSN & \\
\hline Jul-82 & $7 / 20 / 82$ & 29 & $242-1 \mathrm{H}$ & 222000 & 237000 & 0 & EVAPCONC & \\
\hline Aug-82 & $8 / 4 / 82$ & 36 & 29 & 184000 & 195000 & 0 & CONCSN & \\
\hline Aug -82 & $8 / 20 / 82$ & 36 & 29 & 180000 & 189000 & 0 & CONCSN & \\
\hline Aug-82 & $8 / 20 / 82$ & 29 & $242-1 \mathrm{H}$ & 271000 & 289000 & 0 & EVAPCONC & \\
\hline Sep-82 & $9 / 8 / 82$ & 36 & 29 & 127000 & 134000 & 0 & CONCSN & \\
\hline Sep-82 & $9 / 9 / 82$ & 37 & 29 & 72000 & 78000 & 0 & CONCSN & \\
\hline Sep-82 & $9 / 20 / 82$ & 29 & $242-1 \mathrm{H}$ & 117000 & 116000 & 0 & EVAPCONC & \\
\hline Oct-82 & $9 / 24 / 82$ & 13 & 29 & 182000 & 192000 & 0 & CONCSN & \\
\hline Oct-82 & $10 / 15 / 82$ & 37 & 29 & 176000 & 184000 & 0 & CONCSN & \\
\hline Nov-82 & $10 / 27 / 82$ & 36 & 29 & 184000 & 192000 & 0 & CONCSN & \\
\hline Nov-82 & $11 / 20 / 82$ & 29 & $242-1 \mathrm{H}$ & 136000 & 140000 & 0 & EVAPCONC & \\
\hline
\end{tabular}


WSRC-TR-93-609

\begin{tabular}{|c|c|c|c|c|c|c|c|c|}
\hline Dec-82 & $12 / 2 / 82$ & 36 & 29 & 167000 & 180000 & 0 & CONCSN & \\
\hline Dec-82 & $12 / 18 / 82$ & 37 & 29 & 93000 & 102000 & 0 & CONCSN & \\
\hline Dec-82 & $12 / 20 / 82$ & 29 & $242-1 \mathrm{H}$ & 266000 & 240000 & 0 & EVAPCONC & \\
\hline $\operatorname{Jan}-83$ & $12 / 22 / 82$ & 13 & 29 & 78000 & 84000 & 0 & CONCSN & \\
\hline $\operatorname{Jan}-83$ & $1 / 12 / 83$ & 36 & 29 & 137000 & 143000 & 0 & CONCSN & \\
\hline $\operatorname{Jan}-83$ & $1 / 20 / 83$ & 29 & $242-1 \mathrm{H}$ & 279000 & 294000 & 0 & EVAPCONC & \\
\hline Apr-83 & $4 / 7 / 83$ & 36 & 29 & 166000 & 178000 & 0 & CONCSN & \\
\hline May-83 & $5 / 18 / 83$ & 36 & 29 & 167000 & 174000 & 0 & CONCSN & \\
\hline May-83 & $5 / 20 / 83$ & 29 & $242-1 \mathrm{H}$ & 157000 & 175000 & 0 & EVAPCONC & \\
\hline Jun-83 & $6 / 3 / 83$ & 36 & 29 & 182000 & 189000 & 0 & CONCSN & \\
\hline Jun-83 & $6 / 16 / 83$ & 36 & 29 & 190000 & 209000 & 0 & CONCSN & \\
\hline Jun-83 & $6 / 20 / 83$ & 29 & $242-1 \mathrm{H}$ & 381000 & 385000 & 0 & EVAPCONC & \\
\hline Jul-83 & $7 / 9 / 83$ & 37 & 29 & 175000 & 201000 & 0 & CONCSN & \\
\hline Jul-83 & $7 / 20 / 83$ & 29 & $242-1 \mathrm{H}$ & 160000 & 168000 & 0 & EVAPCONC & \\
\hline Aug-83 & $8 / 6 / 83$ & 37 & 29 & 179000 & 199000 & 0 & CONCSN & \\
\hline Aug-83 & $8 / 20 / 83$ & 29 & $242-1 \mathrm{H}$ & 331000 & 335000 & 0 & EVAPCONC & \\
\hline Aug-83 & $8 / 21 / 83$ & 37 & 29 & 161000 & 177000 & 0 & CONCSN & \\
\hline Aug-83 & $8 / 21 / 83$ & 24 & 29 & 11000 & 11000 & 0 & CONCSN & \\
\hline Sep-83 & $9 / 2 / 83$ & 37 & 29 & 12000 & 14000 & 0 & CONCSN & \\
\hline Sep-83 & $9 / 2 / 83$ & 24 & 29 & 7000 & 8000 & 0 & CONCSN & \\
\hline Sep-83 & $9 / 3 / 83$ & 37 & 29 & 43000 & 44000 & 0 & CONCSN & \\
\hline Sep-83 & $9 / 5 / 83$ & 37 & 29 & 117000 & 121000 & 0 & CONCSN & \\
\hline Sep-83 & $9 / 20 / 83$ & 29 & $242-1 \mathrm{H}$ & 220000 & 228000 & 0 & EVAPCONC & \\
\hline Oct-83 & $10 / 20 / 83$ & 29 & $242-1 \mathrm{H}$ & 45000 & 56000 & 0 & EVAPCONC & \\
\hline Nov-83 & $10 / 29 / 83$ & 36 & 29 & 161000 & 167000 & 0 & CONCSN & \\
\hline Nov-83 & $11 / 20 / 83$ & 29 & $242-1 \mathrm{H}$ & 269000 & 283000 & 0 & EVAPCONC & \\
\hline Dec-83 & $11 / 25 / 83$ & 37 & 29 & 184000 & 191000 & 0 & CONCSN & \\
\hline Dec-83 & $12 / 20 / 83$ & 29 & $242-1 \mathrm{H}$ & 120000 & 127000 & 0 & EVAPCONC & \\
\hline $\operatorname{Jan}-84$ & $1 / 20 / 84$ & 29 & $242-1 \mathrm{H}$ & 49000 & 49000 & 0 & EVAPCONC & \\
\hline Aug-84 & $8 / 20 / 84$ & 29 & & 0 & 4000 & 0 & MUSCADD/TRAN & Concentrate Transfer System \\
\hline Apr-86 & $4 / 18 / 86$ & 30 & 29 & 74000 & 77000 & 0 & SNATE & \\
\hline Jul-87 & $7 / 31 / 87$ & 29 & $242-1 \mathrm{H}$ & 2000 & 2000 & 0 & EVAPCONC & \\
\hline Jun-88 & $6 / 30 / 88$ & 29 & $242-1 \mathrm{H}$ & 3000 & 3000 & 0 & EVAPCONC & \\
\hline Jul-88 & $7 / 31 / 88$ & 29 & $242.1 \mathrm{H}$ & 1000 & 8000 & 0 & EVAPCONC & \\
\hline
\end{tabular}


WSRC-TR-93-609

\section{APPENDIX IV}

Sketch of Risers on Tank 29

and

Modifications in Progress 
Sketch of Risers on Tank 29

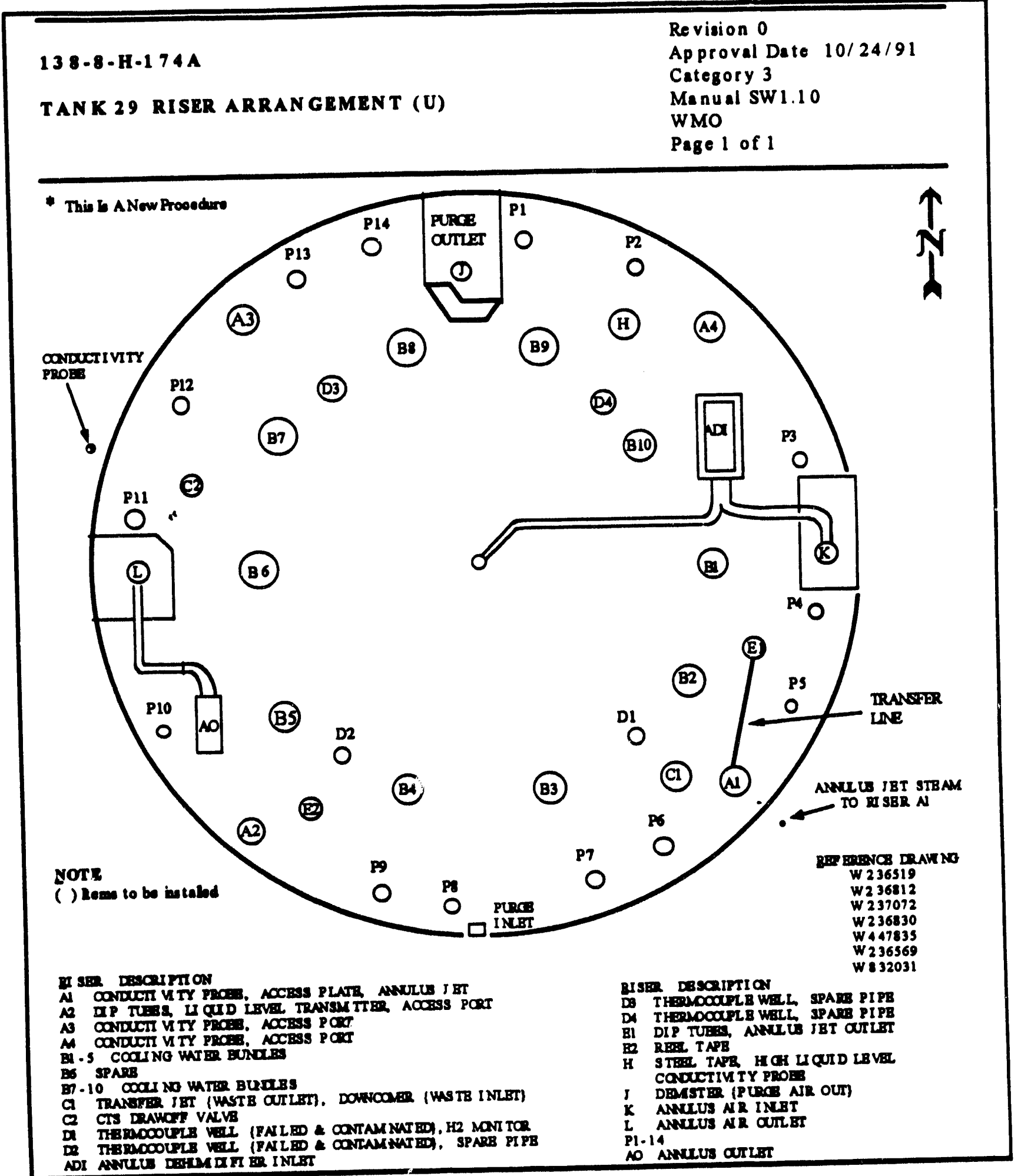




\section{Modifications To Tank 29}

Riser B6

Riser Cl

Riser D1

Riser D2

Riser D3

Riser D4

Riser E1

Riser H
Convert spare riser to contain new slurry pump and spray chamber

After the existing Transfer Jet (TJ) is used to remove some salt, a new Telescoping Transfer Jet (TTJ) with Spray Chamber will be added.

Remove failed thermocouple and $\mathrm{H}_{2}$ monitor. Then install a new riser plug and inlet for annulus jet outlet (for pumping liquid from annulus back into Tank 29)

Remove existing failed thermocouple well and install a new riser plug.

Change existing thermowell to mining thermowell, replace existing riser plug with a new riser plug with a caustic addition facility, an inhibited water addition pipe, and an inspection port with steel tape for measuring liquid level.

Replace riser plug and thermocouple well with a new riser plug. A variable depth sampler and mining of a thermocouple well to near the bottom of tank will be in this riser.

Remove dip tubes and annulus jet outlet. Add slurry pump with spray chamber.

Remove steel tape and high liquid level conductivity probe and add a slurry pump with a spray chamber. 
WSRC-TR-93-609

\section{APPENDIX V}

Active Permits Relating To Waste Removal 
WSRC-TR-93-609

Active Permits Relating To Waste Removal

National Environmental Policy Act:

1. ERDA-1537 "Final Environmental Impact Statement - Waste Management Operations - Savannah River Plant - Aiken, South Carolina."

2. DOE-EIS-0062 "Final Environmental Impact Statement - Supplement to ERDA1537 - Waste Management Operations, Savannah River Plant, Aiken, South Carolina - Double Shelled Tanks for Defense High Level Radioactive Waste Storage."

Federal Facility Agreement:

3. Savannah River Site Federal Facility Agreement, Administrative Docket Number: 89-05-FF

Land Disposal Restriction-Federal Facility Compliance Agreement:

4. Federal Facility Compliance Agreement; Savannah River Site, EPA Docket \#9101-FFR, EPA ID \#SCI 890008989

South Carolina Department of Health and Environmental Control Industrial Wastewater Permit

5. Construction Permit No. 17, 424-IW, "F \& H Area High Level Radioactive Waste Tank Farms", 3 March, 1993.

South Carolina Department of Health and Environmental Control Air Quality Control Permit

6. Permit to Operate Seven (7) Diesel Generators at Waste Management Facilities in H-Area - Permit \#0080-0041.

National Pollution Discharge and Elimination System:

7. NPDES Permit for Savannah River Site; Permit \# SC000175.

South Carolina Department of Health and Environmental control Domestic Water Permit:

8. Permit SC\#405556: H-Area Facilities

South Carolina Department of Health and Environmental Control Sanitary Water Permit:

9. Permit \#12910 and Addendum: H-Area Facilities. 
WSRC-TR-93-609

\section{APPENDIX VI}

Analytical Data From Tank 29 
WSRC-TR-93-609

Analytical Results from Supernate Sample taken from Tank 29 on 11/23/92

\begin{tabular}{|c|c|c|}
\hline Density & $(\mathrm{g} / \mathrm{ml})$ & 1.47 \\
\hline $\begin{array}{l}\mathrm{Na} \\
\mathrm{K} \\
\mathrm{Al}\end{array}$ & $\begin{array}{l}\text { (molar) } \\
\text { (molar) } \\
\text { (molar) }\end{array}$ & $\begin{array}{l}14 \\
0.086 \\
0.93\end{array}$ \\
\hline $\mathbf{M n}$ & (ppm) & 0.3 \\
\hline $\mathbf{F e}$ & (ppm) & 2.3 \\
\hline $\mathbf{S i}$ & (ppm) & 25 \\
\hline As & (ppm) & $<19$ \\
\hline $\mathbf{B a}$ & (ppm) & 1.4 \\
\hline $\mathrm{Cd}$ & (ppm) & 0.75 \\
\hline $\mathrm{Cr}$ & (ppm) & 407 \\
\hline $\mathbf{P b}$ & (ppm) & $<51$ \\
\hline Se & (ppm) & $<235$ \\
\hline Ag & (ppm) & 0.21 \\
\hline NO3 & (molar) & 1.66 \\
\hline $\mathrm{NO}^{2}$ & '(molar) & 2.38 \\
\hline $\mathrm{SO}^{4}$ & (molar) & 0.012 \\
\hline $\mathrm{PO}^{4}$ & (molar) & $<0.01$ \\
\hline $\mathrm{Cl}$ & (molar) & 0.017 \\
\hline $\mathbf{F}$ & (ppm) & $<8$ \\
\hline Oxalate & (molar) & $<0.01$ \\
\hline Total OH & (molar) & 6.5 \\
\hline $\mathrm{AlO}^{2}$ & (molar) & 0.93 \\
\hline Cs-137 & $(\mathrm{d} / \mathrm{m} / \mathrm{ml})$ & $6.5 \mathrm{E} 09$ \\
\hline Cs-134 & $(\mathrm{d} / \mathrm{m} / \mathrm{ml})$ & $2.0 \mathrm{E} 07$ \\
\hline Ru-106 & $(\mathrm{d} / \mathrm{m} / \mathrm{ml})$ & 2.0E05 \\
\hline Sb-125 & $(\mathrm{d} / \mathrm{m} / \mathrm{ml})$ & 4.9E04 \\
\hline Co-60 & $(\mathrm{d} / \mathrm{m} / \mathrm{ml})$ & 4/7E03 \\
\hline Eu-154 & $(\mathrm{d} / \mathrm{m} / \mathrm{ml})$ & $<900$ \\
\hline Sn-126 & $(\mathrm{d} / \mathrm{m} / \mathrm{ml})$ & 1/0E04 \\
\hline Sr-89/90 & $(\mathrm{d} / \mathrm{m} / \mathrm{ml})$ & 8.5E05 \\
\hline Sr error & & $\pm 14 \%$ \\
\hline Tc-99 & $(\mathrm{d} / \mathrm{m} / \mathrm{ml})$ & 1.15E06 \\
\hline U-238 & (ppm) & 2.2 \\
\hline U-235 & (ppm) & 0.44 \\
\hline Total Alpha & & 1.0E07 \\
\hline Total B/G & & 5.4E09 \\
\hline
\end{tabular}


Supernate Sample History Of Tank 29

\begin{tabular}{|c|c|c|c|c|c|}
\hline Date & Sp. Gr. & pH & NO2 (M) & NO3 (M) & OH (M) \\
\hline $11 / 28 / 92$ & 1.4300 & & 2.3800 & 1.6600 & 6.5000 \\
\hline $12 / 26 / 91$ & 1.4530 & $>14$ & 1.6100 & 1.9800 & 5.7500 \\
\hline $06 / 23 / 91$ & 1.4525 & 14.00 & 2.3200 & 2.1300 & 5.1700 \\
\hline $01 / 03 / 90$ & & & & & \\
\hline $12 / 15 / 89$ & 1.4430 & 13.95 & 2.1900 & 2.0500 & 6.2900 \\
\hline $05 / 22 / 89$ & 1.4139 & 13.57 & 2.3200 & 1.8000 & 4.8800 \\
\hline $08 / 22 / 88$ & 1.3657 & 13.78 & 1.9200 & 1.7100 & 5.0200 \\
\hline $07 / 17 / 87$ & 1.1354 & 13.58 & 1.4200 & 1.1200 & 4.1700 \\
\hline $07 / 17 / 87$ & 1.1354 & 13.58 & 1.4200 & 1.1200 & 4.1700 \\
\hline $02 / 26 / 85$ & 1.4000 & & 1.3000 & 1.3000 & 6.3000 \\
\hline $01 / 11 / 85$ & & & & & \\
\hline $10 / 12 / 84$ & 1.4600 & 14.48 & 2.1400 & 1.5900 & 3.6300 \\
\hline $09 / 17 / 84$ & & & & & \\
\hline $08 / 16 / 83$ & 1.5600 & 14.95 & 2.0100 & 1.7200 & 10.8200 \\
\hline $09 / 10 / 82$ & 1.4800 & 14.70 & 1.9000 & 1.5000 & 7.0000 \\
\hline $02 / 15 / 82$ & 1.3500 & & 2.2000 & 2.5000 & 4.7000 \\
\hline $09 / 09 / 81$ & 1.2400 & 13.20 & 0.2000 & 0.2000 & 1.2000 \\
\hline $11 / 10 / 80$ & 1.5000 & 15.00 & 3.0000 & 2.8000 & 1.6000 \\
\hline $06 / 20 / 80$ & 1.4000 & & 0.3800 & 4.7000 & 0.8800 \\
\hline $06 / 17 / 80$ & 1.4000 & 13.80 & 0.3000 & 4.8000 & 1.1000 \\
\hline $06 / 10 / 80$ & 1.3000 & 13.80 & 0.3000 & 4.8000 & 1.1000 \\
\hline $05 / 28 / 80$ & 1.3800 & 13.20 & 0.3000 & 5.3000 & 1.1000 \\
\hline $05 / 19 / 80$ & 1.5700 & 12.70 & 0.7000 & 6.0000 & 1.1900 \\
\hline $02 / 20 / 80$ & 1.4300 & 11.80 & 2.8600 & 1.7000 & 7.4900 \\
\hline $01 / 18 / 80$ & 1.4900 & & 2.1500 & 3.4900 & 8.6100 \\
\hline $07 / 14 / 76$ & & 13.20 & 2.2000 & 2.4000 & 4.9000 \\
\hline $08 / 01 / 71$ & & & & & \\
\hline & & & & & \\
\hline
\end{tabular}



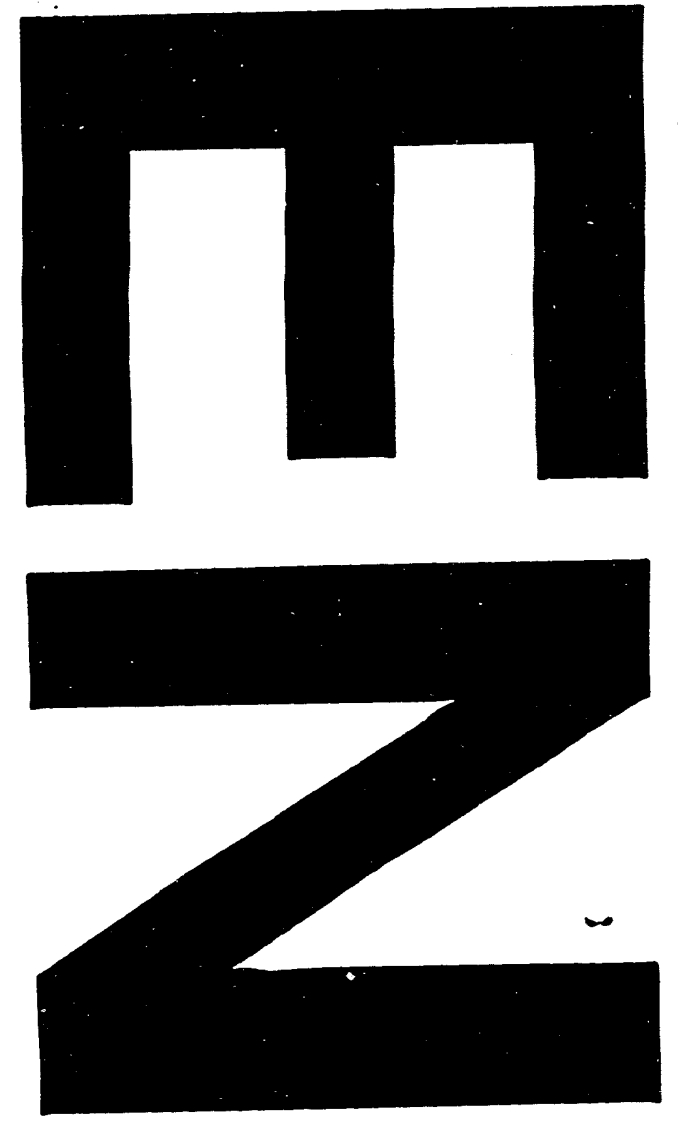

L
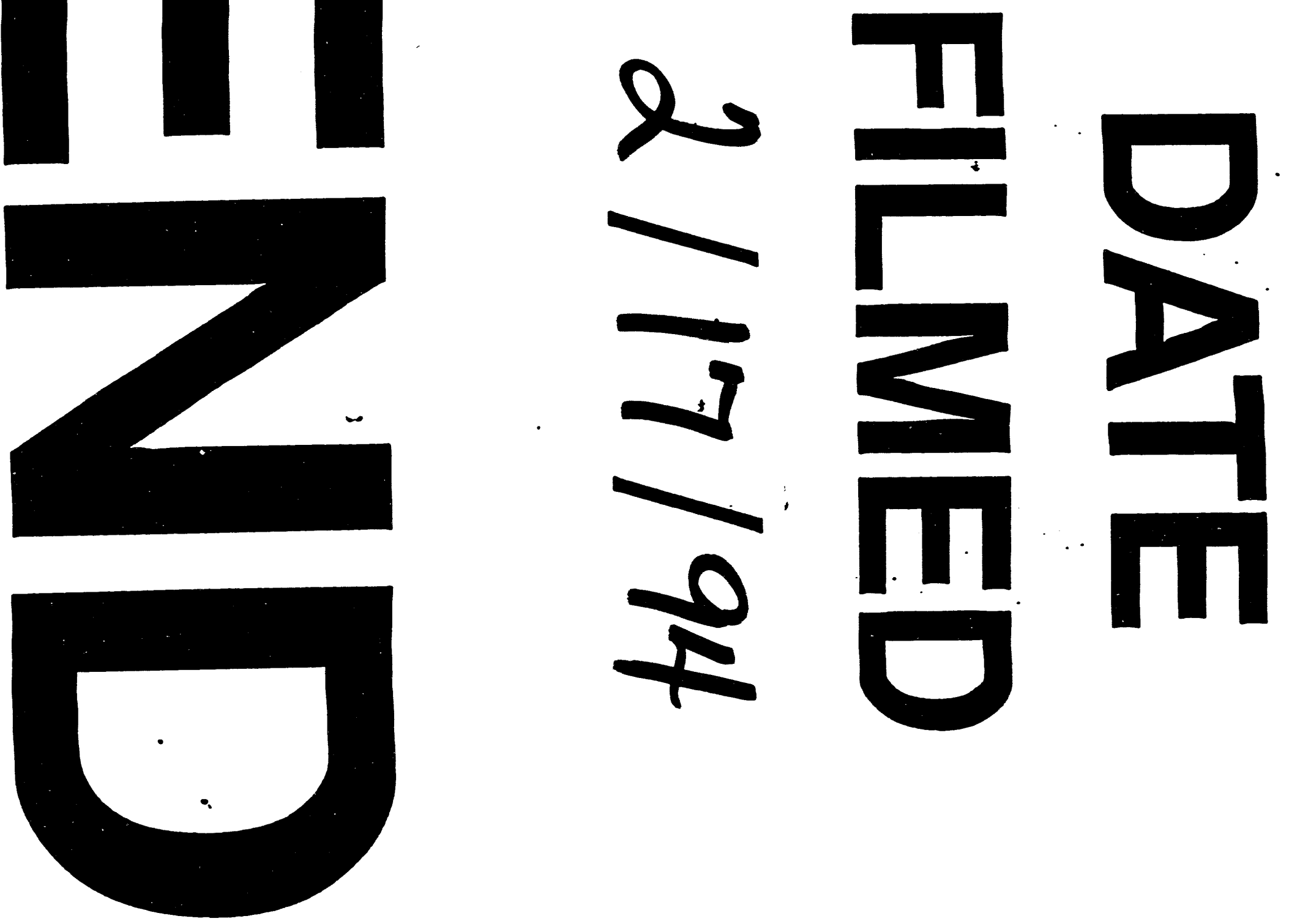

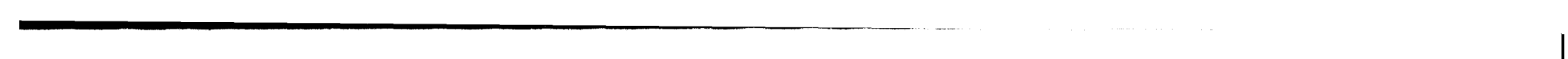